\title{
Invertebrate Tissue and Cells
}

National Cancer Institute

\section{Source}

National Cancer Institute. Invertebrate Tissue and Cells. NCI Thesaurus. Code C18859.

Tissue and cells from the general category of the king dom Animalia (multicellular animals) including those phyla whose members lack a notochord. 